\title{
LA MÚSICA EN LA REPRESENTACIÓN \\ DE LA MONARQUÍA EN LA CIUDAD DE VALENCIA (1829): CANTATA A LA REINA MARÍA CRISTINA DE BORBÓN DE FRANCISCO ANDREVÍ CASTELLÁ
} (1786-1853)

\author{
MUSIC IN THE REPRESENTATION \\ OF THE MONARCHY IN THE CITY OF VALENCIA \\ (1829): CANTATA A LA REINA MARÍA CRISTINA \\ DE BORBÓN DE FRANCISCO ANDREVÍ CASTELLÁ
} (1786-1853)

RESUMEN: El 30 de septiembre de 1829 se inició el viaje de María Cristina de Borbón a su futuro enlace con Fernando VII. Una de las recepciones con mayor trascendencia en el recorrido fue la protagonizada por la ciudad de Valencia, entre cuyas muestras de fidelidad estuvo el encargo e interpretación de la Cantata a la Reina María Cristina de Borbón, compuesta por Francisco Andreví Castellá (1786-1853). En este trabajo se estudia hasta qué grado esta composición contribuyó al programa artístico desarrollado y a la proyección de la imagen de la monarquía durante los últimos años del reinado de Fernando VII. 
Palabras clave: monarquía, Valencia, Andreví, María Cristina de Borbón, música

ABSTRACT: On September 30, 1829, María Cristina de Borbón and her family began the journey that would culminate in her marriage to Fernando VII. One of the most important receptions along the way took place in the city of Valencia, where one of the tributes consisted of the commission and performance of the Cantata a la Reina Maria Cristina de Borbón by Francisco Andreví Castellá (1786-1853). This paper looks at the extent to which this composition contributed to the artistic program and to the projection of the image of the monarchy during the last years of the reign of Fernando VII.

Key words: monarchy, Valencia, Andreví, María Cristina de Borbón, music

\section{INTRODUCCIÓN}

El concierto de matrimonios reales, con el deseado fruto de un heredero al trono, ha sido una de las claves de la política europea y un medio para asegurar, casi exclusivamente, la pervivencia de la monarquía y el poder. Dentro de este enfoque, el de la continuidad dinástica, es donde hay que situar el programa artístico y musical desarrollado para las festividades por los desposorios de María Cristina de Borbón y Fernando VII (1829). ${ }^{1}$

Tras la muerte de la tercera esposa del rey, María Josefa Amalia de Sajonia (1829), España atravesaba un período de incertidumbre por la falta de descendencia directa, lo que se sumaba al ambiente de represión tras la finalización del Trienio Liberal y la restitución en el trono a Fernando VII. Con el fin de mantener las prerrogativas propias del Antiguo Régimen, al mismo tiempo que procurando recuperar la fidelidad del pueblo, durante este periodo se organizaron festividades de carácter público sobre acontecimientos políticos, los habituales del ciclo vital de la familia real -cumpleaños, desposorios, exequias, etc.-, así como visitas, entradas y proclamaciones reales. Tal como apunta Ester Alba, tanto las cuestiones organizativas como los elementos artísticos de estas ceremonias se mantuvieron idénticos a los que

1. Sobre el arte y el ritual en el ceremonial nupcial de la corte, véase: INMACULADA RodRíGUEz Moya: Himeneo en la corte: poder, representación y ceremonial nupcial en el arte y la cultura simbólica, Madrid: Editorial CSIC Consejo Superior de Investigaciones Científicas, 2013; InMaCulada RodríGuez MoyA: «Epitalamios e himeneos. Iconografía y literatura nupcial en las cortes del Barroco», en Imago. Revista de Emblemática y Cultura Visual, 2, 2010, pp. 7-24. 
conformaban la fiesta barroca, pero la novedad estaba en el objeto de festejo y el carácter político-patriótico. ${ }^{2}$

La imagen de la monarquía proyectada en las festividades en torno a la familia real guarda estrecha relación con la orientación e ideario del monarca y las consecuentes reformas que se sucedían en la corte. En este sentido, cabe señalar que, desde una perspectiva artística, el regreso de Fernando VII supondría un resurgir de las fórmulas del Barroco, pero adaptadas a las necesidades de un nuevo tiempo. La sustitución como primer pintor de Cámara del rey de Francisco de Goya por Vicente López, uno de los pintores más representativos de la continuidad del tardobarroco en el XIX, muestra la determinación absolutista del monarca. ${ }^{3}$ Este fenómeno regresivo también se manifestó en la Real Capilla, la cual sufrió modificaciones y revisiones al menos en tres ocasiones $(1815,1820$ y 1824). La pretensión de Fernando VII fue la de mantener el culto con la magnificencia de épocas anteriores, especialmente tras la situación de precariedad que caracterizó el reinado de José I. Para tal fin se determinó aumentar el número de intérpretes de modo que la estructura, tanto de voces como de instrumentos, permitiera mostrar el esplendor propio de una monarquía absolutista. ${ }^{4}$

Entre los principales festejos públicos celebrados en Valencia en el siglo XIX se situaría la visita de la futura reina María Cristina de Borbón en su tránsito hacia los desposorios con Fernando VII. ${ }^{5}$ La ciudad de Valencia, que

2. Ester Alba PagÁn: «El arte efímero y los artistas valencianos en la primera mitad del siglo XIX: de la fiesta barroca a la fiesta político-patriótica (1802-1833) (I)», Cuadernos de Arte e Iconografía, 16, 1999, pp. 493-530. Para un mayor acercamiento a la evolución de la fiesta y de la imagen de la monarquía española de los siglos XVIII al XIX, desde una perspectiva artística, consúltese: RAFAEL GIL SALINAS: «El símbolo de lo Real: La construcción de la imagen de la monarquía española en el tránsito de los siglos XVIII al XIX», en Concha lomba y JuAn Carlos Lozano (eds.): El recurso a lo simbólico: reflexiones sobre el gusto, II, Actas del simposio, Institución Fernando el Católico, Zaragoza, 2014, pp. 91-117; Víctor Mínguez Cornelles: «La iconografía del poder. Fernando VII y José I. Apoteosis y escarnio en la disputa del trono español», en Alberto Ramos Santana y Alberto Romero Ferrer (eds.): 1808-1812: los emblemas de la libertad, Universidad de Cádiz, Cádiz, 2009, pp. 163-194.

3. SAlinas: El símbolo de lo real, p. 114.

4. Para un acercamiento al estado y recursos de la Real Capilla durante el reinado de Fernando VII, véase: Begoña LoLO: «La música en la Real Capilla después de la Guerra de la Independencia. Breves esbozo del reinado de Fernando VII», Cuadernos de Arte, 26, 1995, pp. 157-169.

5. Para el estudio del arte efímero valenciano y la evolución de la fiesta en el siglo XIX, véase: SuSANA Ferrer Martí: «Arte efímero decimonónico: las fiestas reales y político-patrióticas en la ciudad de Valencia», Tesis de licenciatura, Universitat de València, 1993; MARÍA Pilar Monteagudo Robledo: «El poder monárquico. Fiestas reales e imagen de la monarquía en la Valencia del siglo XVIII», Tesis Doctoral, Universitat de València, 1994; María Pilar Monteagudo Robledo: «Fiestas reales en la Valencia moderna: El espectáculo del poder de una monarquía ideal», en Estudis: revista de historia moderna, 20, 1994, pp. 323-327; Ester Alba Pagán: «Vicio y virtud en la alegoría de exaltación monárquica: del fin del Antiguo Régimen al liberalismo», en Rafael Zafra Molina y José Javier AzAnza López (coor.): Emblemática trascendente: hermenéutica de la imagen, iconología del texto, Universidad de Navarra, Navarra, 2011, pp. 137-148; Ester AlbA PAgÁN: «La pintura y los pintores valencianos durante la guerra de la independencia y el reinado de Fernando VII», Tesis Doctoral, Universitat de València, 2003; Ester AlbA PAGÁN: «El arte efímero y los artistas valencianos en la primera mitad del siglo XIX: de la fiesta barroca a la fiesta políticopatriótica (1802-1833) (II)», Cuadernos de Arte e Iconografía, 19, 2001, pp. 183-212. 
durante los siglos del absolutismo fue ciudad festiva por excelencia, ${ }^{6}$ mantuvo en su celebración, aunque de forma más sencilla, las características tradicionales de la fiesta barroca con la elevación de monumentos efímeros, la iluminación general de la ciudad, la música y los fuegos artificiales. La descripción de los elementos que conformaban los festejos se halla principalmente en la prensa del momento, las memorias y descripciones incluidas en las relaciones de fiestas y en las actas y documentación sobre fiestas que se ha conservado en el Archivo Municipal de Valencia. Si bien el arte ef ímero desarrollado para este acontecimiento ha sido abordado por parte de investigadoras como Ester Alba Pagán y Mari Carmen Hernández y Sara Reig, ${ }^{7}$ no sucede lo mismo con la música interpretada, a pesar de su intensiva utilización en estos eventos. De hecho, la actividad musical originada para las fiestas públicas del Antiguo Régimen no ha sido objeto de estudio hasta fechas recientes. ${ }^{8}$ Esta circunstancia podría deberse a la escasa información que proveen las fuentes principales y al carácter perecedero de su material. En este sentido, cabe indicar que el objeto de este estudio es el aspecto musical contextualizado en el programa artístico general. En la organización y ejecución de las celebraciones se encuentra la participación de maestros y compositores de gran prestigio. El estudio del contexto y el análisis de los lenguajes artísticos desarrollados permitirá tener una visión más amplia

6. Véase Víctor Mínguez Cornelles e Inmaculada Rodríguez Moya: Las ciudades del absolutismo: arte, urbanismo y magnificencia en Europa y América durante los siglos XV-XVIII, Castelló de la Plana: Publicaciones de la Universitat Jaume I, 2006.

7. Alba: La pintura y los pintores valencianos, pp. 374-380; Mari Carmen Hernández Perelló Y SARA Reig BALdó: «La permanencia de los efímero. Primeras plasmaciones: Los monumentos erigidos en las visitas de la reina María Cristina a la ciudad de Valencia (1829-1844)», en Archivo de arte valenciano, 88,2007 , pp. $75-82$.

8. Es a partir de la década de 1990 cuando se encuentran la mayor parte de las publicaciones sobre música y fiestas reales, entre otros: María Salud Álvarez Martínez: «Una serenata de Felipe Falconi para la boda de la infanta María Ana Victoria», en Revista de Musicología, 20, 1997, pp. 343-354; ANDrEA Вомві: «La música en las festividades del palacio Real de Valencia en el siglo XVIII», en Revista de Musicología, 18, 1995, pp. 175-228; NiCOLÁs MORALES: «Real Capilla y Festería en el siglo XVIII: nuevas aportaciones para la historia de la institución musical palatina», en Revista de Musicología, 22, 1999, pp. 175-208; JORDI Rifé i Santaló: «La música en Girona durante la visita del archiduque Carlos de Austria», en Revista de Musicología, 20, 1997, pp. 331-342; Cristina Bordas IbÁñez, Luis Robledo Estaire, Tess Knighton y JuAn José Carreras Ares (coor.): Aspectos de la cultura musical en la corte de Felipe II, Madrid: Fundación Caja Madrid-Alpuerto, 2000; EMILIo Ros-Fábregas: «Music and ceremony during Charles V's 1519 visit to Barcelona», en Early Music History, 23, 1995, pp. 374-389; Tess Knighton y Carmen Morte García: «Ferdinand of Aragon's entry into Valladolid in 1513: The triumph of a Christian King», en Early Music History, 18, 1999, pp. 119-163; BEgOÑa LoLO: «Las bodas de Carlota Joaquina con Joao VI (1785)», en José Martínez Millán y María Paula Marçal Lourenço (coor.): Las relaciones discretas entre las Monarquías Hispana y Portuguesa: Las Casas de las Reinas (Siglos XV-XIX). Actas del Congreso Internacional, Polifemo, Madrid, 2008, pp. 1847-1884 (Volumen 3); Más recientemente, destaca la Tesis Doctoral de María José De la Torre Molina: «Música y ceremonial en las fiestas reales de Proclamación de España e Hispanoamérica (1746-1814)», Tesis Doctoral, Universidad de Granada, 2003; convertida en el libro: $M u ́-$ sica y ceremonial en las fiestas reales de Proclamación de España e Hispanoamérica (1746-1814), Granada: Editorial Universidad de Granada, 2004. De la misma autora, sobresale: «La música en las Fiestas Reales de la Málaga Napoleónica (1810-1812)», en Revista de Musicología, 32, 2009, pp. 447-473. 
de la trayectoria y producción de sus creadores y recrear de un modo más completo los programas artísticos ejecutados en las fiestas reales.

\section{VIAJE POR EL ENLACE DE MARÍA CRISTINA CON FERNANDO VII}

El 9 de septiembre de 1829 María Cristina de Borbón, princesa de las Dos Sicilias, fue solicitada en audiencia pública como esposa del rey de España y de las Indias Fernando VII. La noticia del enlace real y sus causas oficiales fueron difundidas entre el pueblo español mediante real decreto firmado por el monarca. Según dicha publicación: ${ }^{9}$

Las reverentes súplicas que han elevado a mis reales manos con la expresión de la más acendrada lealtad, así el Consejo como la Diputación de mis reinos y otras muchas Corporaciones, pidiéndome afiance con nuevo matrimonio la consoladora esperanza de dar sucesión directa a mi Corona, me han inclinado a ceder a sus ruegos, teniendo consideración a los intereses y prosperidad de mis amados vasallos. Con este recto fin, y persuadido de las grandes ventajas que resultarán a la Religión y al Estado de mi enlace con la serenísima princesa DoÑa MARÍA CRISTINA DE BorbóN.

El viaje de la princesa al encuentro con Fernando VII se inició el 30 de septiembre en compañía de sus padres, los Reyes de las Dos Sicilias, y la corte napolitana. Según consta en el periódico Mercurio de España, al carruaje de la futura reina de España le acompañaron hasta 17 coches y 5 furgones más. El recorrido de cada uno de los transportes, así como el itinerario completo de la princesa, fue detallado en la citada publicación para seguimiento de sus súbditos. ${ }^{10}$

Algunos de los lugares -antes de su entrada en España- donde consta que fueron recibidos con felicitaciones y muestras de fidelidad fueron: Albano, donde visitaron al Papa Pío VIII y fueron agasajados con una demostración pública; Turín, donde tuvieron que detenerse por un fuerte temporal; y la ciudad de Grenoble, al sureste de Francia, en donde se encontraron con los infantes Francisco de Paula y Luisa Carlota, la duquesa de Berry, la duquesa de Orleans y su marido. Estos últimos, los acompañarían el resto del viaje. ${ }^{11}$

9. Decretos del rey Nuestro Señor Don Fernando VII, y Reales Órdenes, Resoluciones y Reglamentos Generales expedidos por las Secretarias de Despacho Universal y Consejos de S.M. desde I ${ }^{\circ}$ de Enero hasta fin de Diciembre de 1829. Josef MARÍA DE NiEVA, tomo decimocuarto, de orden de S.M., Madrid: Imprenta Real, 1830, pp. 285-286.

10. Mercurio de España, 10, 1829, pp. 251-252.

11. Descripcion del viage de sus magestades D. Francisco I y Da. Maria Isabel, Reyes de Nápoles, de la Princesa Real Da. Maria Cristina, futura Reina de España, de S.A. la Duquesa de Berri y de los Serenísimos Señores Infantes de España D. Francisco de Paula y Da. Luisa de Borbón, Valencia: José Gimeno,1829. Un es- 
El día 12 de noviembre entraron en territorio español, en cuya frontera estaban el conde de Bornos, el de España, Capitán General de Cataluña y las principales autoridades del Principado. Entre las alocuciones dirigidas a Sus Majestades y María Cristina en esta entrada se cita el siguiente fragmento: ${ }^{12}$

\begin{abstract}
Serenísima señora: sin más mérito que mi acendrada lealtad al Rey, mi augusto amo, he debido a su real clemencia el nombramiento para salir a recibir a $\mathrm{V}$ [uestra] A[lteza] y sus señores padres a este punto, lisonjeándome la fortuna de ser el primero de mis paisanos en este territorio que tiene la honra de ofrecer a los pies de V[uestra] A[lteza] los debidos homenajes de rendimiento, felicitándola al mismo tiempo por el enlace que va a contraer con el Rey más amado de sus pueblos. Desearé que V[uestra] A[lteza] se dé por bien servida en el viaje hasta la corte, a lo que dedicaré mis más constantes desvelos.
\end{abstract}

Desde la frontera hasta su llegada a la corte en Madrid, María Cristina de Borbón y su comitiva fueron recibidos con felicitaciones de ayuntamientos y autoridades civiles, militares y eclesiásticas de los diferentes pueblos por los que transitaron. ${ }^{13}$ De entre estas muestras de fidelidad e interés, según Mercurio de España, destacaron las demostraciones de las ciudades de Barcelona y Valencia. ${ }^{14}$

El día 15 de noviembre entraron en la ciudad de Barcelona, donde fueron agasajados durante cinco días consecutivos. Entre los acontecimientos del ámbito artístico sobresalieron, además de la música de los regimientos que estaban en las calles, la interpretación de un Te Deum, diversos bailes -de máscara, de trajes y también folclóricos- y la representación del drama $I l$ Ristoro felice compuesto expresamente para celebrar el enlace próximo entre Fernando VII y la homenajeada María Cristina de Borbón. ${ }^{15}$

Prosiguiendo el viaje de la princesa hacia el encuentro con Fernando VII, llegarían al Reino de Valencia por Vinaròs, donde fueron recibidos por una comitiva en representación del Ayuntamiento de Valencia. La entrada en la ciudad tendría lugar el 29 de noviembre. En posteriores apartados se profundizará en los actos llevados a cabo en su paso por la ciudad de Valencia y, más concretamente, en el contexto en el que se interpretó la Cantata.

tudio sobre el recorrido de María Cristina de Borbón puede encontrase en: SARA NAVARro LaLANDA: «Un modelo de política musical en una sociedad liberal: María Cristina de Borbón-Dos Sicilias (1806- 1878)», Tesis Doctoral, Universidad Autónoma de Madrid, 2013, p. 63.

12. Mercurio de España, 11, 1829, p. 329.

13. Según el itinerario señalado por SS.MM. Sicilianas en su viaje desde Barcelona a la corte y recogido por Mercurio de España, los lugares por los que transitó la comitiva fueron: Barcelona, Villafranca, Tarragona, Cambrils, Perelló, Tortosa, Vinaroz, Alcalá de Chisbert, Castellón de la Plana, Valencia, S. Felipe (Xàtiva), Almansa, Chinchilla, Minaya, Pedernoso, Corral, Aranjuez, Madrid. Véase: Mercurio de España, 11,1829 , p. 330 .

14. Mercurio de España, 12, 1829, p. 429.

15. Diario de Barcelona, 319-323, 1829. 
El último trayecto de la comitiva hasta la corte haría su receso en el Real Sitio de Aranjuez, recibiéndoles los infantes Carlos, Francisca, Francisco de Paula y Luisa Carlota. Allí tuvo lugar el encuentro entre María Cristina y el rey el día 10 de diciembre, tan solo un día antes de la gran ceremonia de los desposorios.

Su entrada en Madrid, el 11 de diciembre, se regiría por la etiqueta y ceremonial correspondiente a la de una futura reina. La escena sería recreada irónicamente por Galdós con la siguiente descripción: ${ }^{16}$

Aquel día de diciembre de 1829 el pueblo de Madrid admiró principalmente la hermosura de la nueva reina, la cual era, según la expresión que corría de boca en boca, «una divinidad». Su cara, incomparablemente graciosa y dulce, tenía un sonreír constante que se entraba, como decían entonces, hasta el corazón de todo el pueblo, despertando ardientes simpatías [...] Jamás paloma alguna entró con más valentía que aquella en el negro nidal de los búhos, y aunque no pudo hacerles amar la luz, consiguió someterles a su talento y albedrío, consiguiendo de este modo que parecieran menos malos. Fue mirada su belleza como un sol de piedad que venía, si bien un poco tarde, a iluminar los antros de venganza y barbarie en que vivía, como un criminal aherrojado, el sentimiento nacional.

\section{CONTEXTO ARTÍSTICO E INTERPRETATIVO DE LA CANTATA: ENTRADA Y FESTEJOS REALES EN VALENCIA}

La futura reina de España María Cristina de Borbón llegó a la ciudad de Valencia el 29 de noviembre de 1829. El Diario de Valencia, primer periódico valenciano, publicaba en su número 59, un himno laudatorio preludio de la feliz llegada: ${ }^{17}$

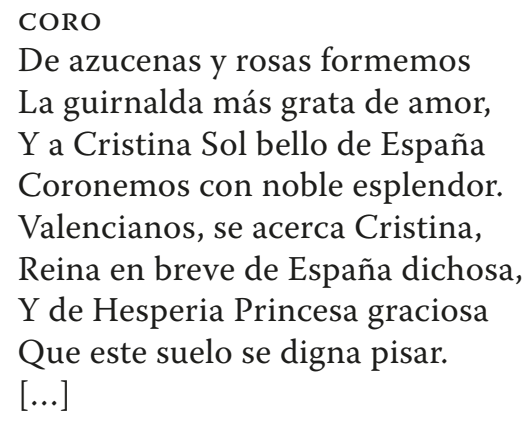

16. Benito Pérez Galdós: Los apostólicos; Un faccioso más y algunos frailes menos, Madrid: Administración de La Guirnalda y Episodios Nacionales, 1885, p. 33.

17. Diario de Valencia, 59, 1829, pp. 289-294. 
La organización de la visita real fue minuciosamente preparada por el Ayuntamiento de Valencia. Según consta en la documentación conservada en el archivo municipal de la corporación se nombró una comisión de festejos, entre cuyos regidores se encontraban: José Guerau de Arellano, José Tamarit y Pastor, Ignacio Guerola y García, Joaquín Miquel y Roca, Joaquín Villarroya y Barón de Llaurí. ${ }^{18}$ Para asegurar las muestras y representación del pueblo se realizó un llamamiento a las corporaciones, gremios y otros particulares.

Los festejos tuvieron lugar hasta el 2 de diciembre, una estancia de tres días donde se mantuvieron las costumbres propias de la fiesta barroca con la tradicional bienvenida del cuerpo de la real Maestranza, el volteo de campanas, la visita a la catedral y las noches de fuegos artificiales, serenatas y bailes. ${ }^{19}$ La ciudad fue engalanada de forma ostentosa con luminarias, flores, telas, retratos y monumentos, situados mayormente a lo largo de la carrera realizada por el cortejo. ${ }^{20}$ Entre las contribuciones artísticas encargadas por el Ayuntamiento y los distintos gremios, sobresalen el Arco triunfal erigido por el gremio de Zapateros; la decoración de la fachada de la Lonja, encomendada por la Junta de Comercio y Agricultura; el castillo de fuegos artificiales para la noche del día 30 de noviembre, dispuesto por el Ayuntamiento; y el concierto ofrecido a la llegada de la comitiva, donde se inserta la obra objeto de estudio. ${ }^{21}$

18. «Antecedentes de festejos por la venida de los Reyes de las dos Sicilias y la Serenísima Señora Infanta Doña Cristina futura Reina de España», Archivo Municipal de Valencia (amv), Fiestas, Ferias y Espectáculos, Clase I, Subclase b: Fiestas Reales.

19. Memoria de los regocijos públicos con que el excelentísimo ayuntamiento de la muy noble, leal y fidelísima ciudad de Valencia celebró el tránsito y permanencia de los muy excelsos y poderosos reyes de las Dos Sicilias, y de su augusta hija la princesa doña María Cristina de Borbón, en su viage a Madrid, con motivo del augusto enlace de S.A. con el rey nuestro Señor (que Dios guarde) publicada por dicha Corporación, Valencia: Imprenta de D. Benito Monfort, 1830.

20. El recorrido fue por la Puerta del Real, plaza de Santo Domingo, calle del Mar, plaza de Santa Catalina, calle de Zaragoza y del Miguelete, plaza de la Catedral, de la Almoina y Palacio de D. Francisco Longa, Capitán general de la provincia. Véase: «Actas y documentos pertenecientes a la comisión de festejos a la venida de SSMM, año 1829», Amv, Fiestas, Ferias y Espectáculos, Clase I, SubClase b: Fiestas Reales.

21. Según la documentación sobre los festejos conservada en el Archivo Municipal de Valencia, algunos de los colectivos que excusaron su participación en la visita debido a la carestía de fondos fueron: el Colegio de Sombrereros, el Gremio de Cortantes y la Cofradía de pobres Ciegos oracioneros. Véase: «Antecedentes de festejos», Amv, Fiestas, Ferias y Espectáculos, Clase I, Subclase b: Fiestas Reales. 


\section{DESCRIPCIÓN DE LAS MANIFESTACIONES ARTÍSTICAS Y ACONTECIMIENTOS DESTACADOS}

El primer monumento que destacar entre los erigidos a lo largo de la carrera, dadas sus dimensiones y carga iconográfica, es el Arco triunfal encargado por el gremio de Zapateros. El monumento, levantado en la hoy desaparecida calle Zaragoza, fue encargado a los profesores de pintura Francisco Royo, y de escultura José Gil. Tal como consta en la descripción del Arco publicada por la imprenta de López, se trataba de un Arco de orden corintio, que fue iluminado por las noches y al que acompañaba una orquesta y fuegos artificiales. ${ }^{22}$ En el lado dirigido hacia la plaza de Santa Catalina se situaban, en el primer zócalo de las columnas de ambos lados, dos estatuas representando la Justicia y la Prudencia. Encima del rebanco del cornijón estaban los escudos de armas de los reyes de España y Nápoles sostenidos por genios con manto real y coronas alegóricas. Se remataba el conjunto triunfal con la estatua de la Fama con la tea de Himeneo en la mano izquierda. Del otro lado, enfrente de la catedral, se situaron dos estatuas que simbolizaban la Paz y la Lealtad. En el centro del rebanco se añadió el escudo de armas del Gremio con dos genios a sus lados en actitud de sostener unas coronas, imagen del obsequio que se tributaba a sus majestades y alteza.

Otro arco triunfal fue erigido frente a la casa Vestuario, pero en este caso encargado por el Ayuntamiento de Valencia. Según la hipótesis de Mari Carmen Hernández y Sara Reig, el monumento levantado en esta ocasión podría corresponder, al menos como diseño previo, con el dibujo conservado en el Museo de la Ciudad (véase Ilustración 1) ${ }^{23}$ Se trata de un boceto $a$ gouache de dos arcos de triunfo con cierto estilo clasicista. El arco representado en la parte inferior sería el que más se acercaría a las descripciones del momento, especialmente por las referencias al «precioso medallón dorado, que de un lado presentaba en bajo relieve el retrato del Rey nuestro Señor, y de otro el de su augusta Esposa». ${ }^{24}$

\footnotetext{
22. «Antecedentes de festejos», Amv, Fiestas, Ferias y Espectáculos, Clase I, Subclase b: Fiestas Reales.

23. HeRnÁndez y ReIG: La permanencia de lo efímero, pp. 75-82.

24. Memoria de los regocijos públicos con que el excelentísimo ayuntamiento..., p. 4.
} 


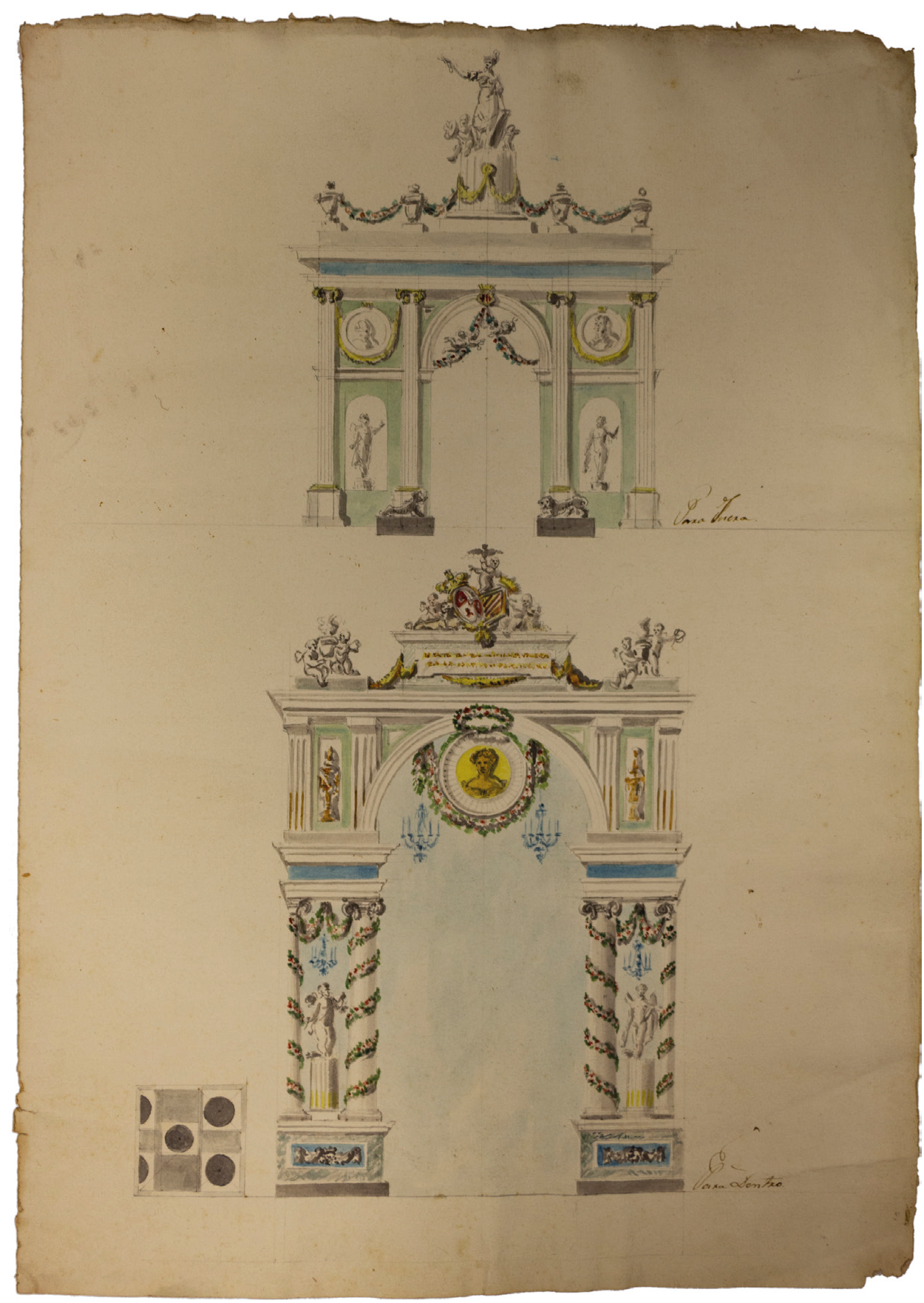

Ilustración 1. Diseño de arcos para la entrada de la infanta $M^{a}$ Cristina de Borbón y Dos Sicilias, Museo de la Ciudad. Ayuntamiento de Valencia. MC/06/243 
Las perspectivas por el enlace entre $\mathrm{M}^{\text {a }}$ Cristina y Fernando VII, con la unión de la corona española y la siciliana, fueron vislumbradas en las manifestaciones ofrecidas por el sector agrario y comercial valenciano. La Junta de Comercio y Agricultura encargó la decoración de la fachada de la Lonja valenciana que fue dirigida por el académico Manuel Fornés. La obra, siguiendo el discurso oficial, era una alegoría al amor y al próximo matrimonio de la princesa con el rey de España. ${ }^{25}$ Según la descripción incluida en el Diario de Valencia, en el centro del frontis del edificio se erigía un templo de orden jónico compuesto, acompañado de un grupo de tres estatuas formado por la representación de: Himeneo, Aglaé, la más joven de las tres Gracias, y el Amor. ${ }^{26}$ En los intercolumnios de ambos lados se colocaron estatuas simbolizando el Comercio y la Agricultura. Todo el conjunto se acompañaba de una galería para la colocación de 33 músicos del Regimiento 17, que tocaron obras diversas durante la noche. En las ventanas laterales del salón se veían pintados, en una de ellas, el Comercio viendo venir a Neptuno de los mares de Sicilia a anunciarle lo que debe esperar del enlace entre $M^{a}$ Cristina y Fernando VII; por otro, se vislumbraban las alegorías de la Agricultura y la Esperanza como matronas que vaticinan la protección. Por último, en la ventana baja del centro sobre el templo figuraba Mercurio, protector de los viajeros volando y Cupido prestándole las alas; y en la ventana alta, Momo, dios del placer y la alegría, como representación de la época feliz que se esperaba. A la suntuosidad de la decoración, contribuiría la iluminación de la fachada con más de seis mil luces colocadas en vasos de color azul y blanco.

Otras obras artísticas menores fueron construidas expresamente para la visita de la futura reina por parte de los distintos gremios de la ciudad, como el gran obelisco erigido en la plaza de la Congregación por el gremio de Horneros; un dosel con retrato de Fernando VII colocado en la plaza de San Cristóbal, encomendado por el gremio de Peineros y Cesteros; o un tablado con estatua de Vulcano costeado por el gremio de Herreros en la plaza del Miguelete. ${ }^{27}$

Entre los acontecimientos más trascendentes en la visita de sus majestades y la princesa, cabe destacar dos momentos o funciones donde se produjo una unión más efectista de las artes. El primero tuvo lugar el mismo día de la llegada, el 29 de noviembre, tras la carrera por las calles de la ciudad. Las reales personas se dirigieron hacia su residencia, el Palacio de Francisco Longa, Capitán general de la provincia, desde cuyo balcón presenciaron la interpretación de la Cantata de Francisco Andreví. ${ }^{28}$ Según el Diario

\footnotetext{
25. Alba: La pintura y los pintores valencianos, pp. 376-377.

26. Diario de Valencia, 62, 1829, pp. 306-307.

27. Memoria de los regocijos públicos con que el excelentísimo ayuntamiento..., pp. 8-10.

28. La estancia de la familia real en el Palacio de Francisco Longa podría deberse al estado tan deplorable en el que se encontraba el Palacio Real desde su destrucción en 1810. Según consta en el mapa trazado
} 
de Valencia del 1 de diciembre, la obra dispuesta por el Ayuntamiento fue ejecutada por una «escogida orquesta» y las «mejores voces de ambos sexos». Se cita: ${ }^{29}$

En una galería dispuesta en la misma plaza de Palacio, acompañada de una escogida orquesta, se ejecutó por las mejores voces de ambos sexos una cantata, cuya letra y música propia del objeto a que se dirigía había dispuesto el Excmo. Ayuntamiento, la que oyeron con agrado y complacencia los Señores Reyes de Nápoles y su excelsa Hija.

El acto se completó con música militar, tal como indica la memoria impresa de estos actos: $:^{30}$

Para la diversión de S[us] M[ajestades] y alivio de las fatigas de su largo viaje tenía el Ayuntamiento prevenida en su galería en la plaza del Palacio una música militar, a la que acompañó otro concierto en que se cantaron con voces de ambos sexos himnos alusivos al feliz arribo de S[us] M[ajestades] a esta ciudad, y al plausible destino de la augusta Princesa Doña María Cristina al Trono de las Españas.

Parece ser que la serenata fue de agrado para los reales visitantes, quienes, a pesar de la meteorología -entre 10 y 11 grados según las propias observaciones del momento-, ${ }^{31}$ se mantuvieron en el exterior del palacio. ${ }^{32}$ Según se recoge en la citada memoria: ${ }^{33}$

Esta serenata que dispuso el Ayuntamiento fue sin duda noblemente sellada con la aprobación de S[us] M[ajestades] y Augusta Princesa, y con el brillante rasgo de la amabilidad de sus Reales Personas que tuvieron la dignación de salir al balcón a oírla a pesar de la crudeza de la estación, con lo que añadiéndose una nueva satisfacción a la ciudad, la tuvo igualmente completa el innumerable concurso que celebró con vítores y vivas toda manera de demostraciones de alborozo tan apreciable dignación de S[us] M[ajestades] y A[ugusta].

por Francisco Ferrer en 1831, la Capitanía General de la ciudad se situaría en el actual Palacio del Marqués de Campo. Véase: Francisco Ferrer: «Plano geométrico de la ciudad de Valencia llamada del Cid», Biblioteca Valenciana, 1831, CartografíaAnt7/6.

29. Diario de Valencia, 62, 1829, p. 306.

30. Memoria de los regocijos públicos con que el excelentísimo ayuntamiento..., p. 6.

31. Diario de Valencia, 60, 1829, p. 297.

32. Otros acontecimientos musicales tuvieron lugar en estos días, entre los que cabe destacar la interpretación de un Te Deum y una Sinfonía en la catedral de Valencia el día 30 de noviembre; una función de baile en casa del conde de Parcent donde sonó música militar; y una serenata por parte de los estudiantes de la Universidad, con orquesta y voces, que incluyó la interpretación de la Jota Estudiantina.

33. Memoria de los regocijos públicos con que el excelentísimo ayuntamiento..., p. 6. 
Por último, cabe resaltar la diversión de fuegos artificiales ofrecida por el Ayuntamiento el día 30 de noviembre por la noche. Para esta ocasión, se construyó una estructura efímera, un templo, que fue adornado con columnas iluminadas con variados colores formando lo que parecía una gran orla alrededor de los retratos del Rey, su futura esposa y los Reyes de las Dos Sicilias. ${ }^{34}$ Como puede intuirse por esta descripción, el boceto de la Ilustración 2, conservado en el archivo municipal del Ayuntamiento, podría haber servido de diseño previo para su ejecución. El castillo de fuegos fue compuesto por «figuras de cipreses, de palmas, de pirámides, de fuentes, de ruedas chispeantes, y de otras mil invenciones ingeniosas». ${ }^{35}$

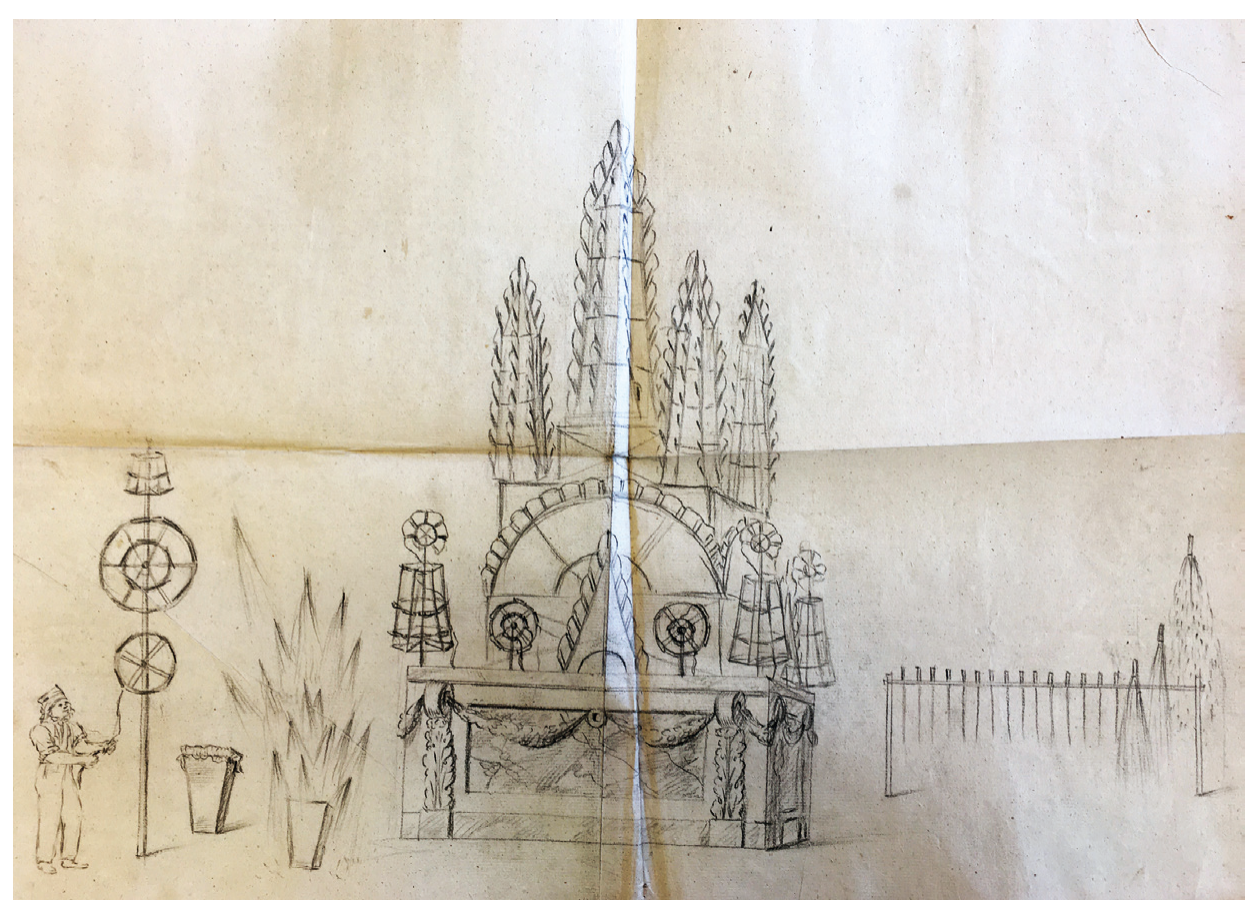

Ilustración 2. Boceto de castillo de fuegos artificiales, en «Actas y documentos pertenecientes a la comisión de festejos a la venida de SSMM, año 1829», AMV, FIESTAS, FERIAS Y ESPECTÁCULOS, CLASE I, SUBCLASE B: Fiestas Reales

34. Memoria de los regocijos públicos con que el excelentísimo ayuntamiento..., p. 7; Diario de Valencia, 63, 1829, p. 315.

35. Memoria de los regocijos públicos con que el excelentísimo ayuntamiento..., p. 7. 


\section{MOMENTO VITAL DE LA GÉNESIS COMPOSITIVA: LA MAESTRÍA DE LA CATEDRAL DE VALENCIA}

Francisco Andreví Castellá (1786-1853) ocupaba la maestría de la catedral de Valencia cuando tuvo lugar la llegada a la ciudad de la comitiva real que acompañaba a María Cristina a su enlace con Fernando VII. ${ }^{36} \mathrm{Su}$ desarrollo y experiencia en dicha capilla era dilatada en el tiempo pues hacía más de diez años -desde el 8 de mayo de 1819- que había sido nombrado su maestro. Fue su primer puesto de relevancia y también el magisterio más largo de su trayectoria.

Durante los años en los que Andreví permaneció en esta catedral realizó su trabajo de forma fiel a los principios de la institución, siendo alabado en múltiples ocasiones por sus composiciones y su entera disposición. Cumplió ampliamente su cometido como compositor depositando en el archivo una gran cantidad de obras (73), ${ }^{37}$ muchas de las cuales han sido copiadas y difundidas en otras instituciones durante décadas. ${ }^{38}$ De entre toda su producción en estos años cabe resaltar la obra objeto de este estudio, la Cantata a la Reina María Cristina de Borbón, y la que se considera la obra maestra de este período, el oratorio El juicio universal (1822), descrito por Carreras i Bulbena como «el mejor oratorio compuesto en España». ${ }^{39}$

Su marcha de la catedral de Valencia vendría motivada principalmente por las dificultades económicas que atravesaba la institución, las cuales obligaron al maestro a solicitar el salario acordado en varias ocasiones. Según carta del 29 de abril de 1824 y tras varias reclamaciones, Andreví expone al cabildo: ${ }^{40}$

[...] que tengo presentadas dos exposiciones hace ya algunos meses en solicitud de que se me pague el salario y distribuciones que he disfrutado antes del 7 de marzo de 1820, y esta es la hora que no se me ha hecho saber resolución alguna, siendo así que se trata de un punto tan urgente e interesante como es el de mis alimentos.

\footnotetext{
36. Sobre la figura de Francisco Andreví en los últimos años cabe destacar el monográfico de GLÒRIA Ballús Casólica y Antonio Ezquerro Esteban: Música en imágenes: Francisco Andreví (1786-1853), músico de iglesia y compositor cosmopolita en un mundo cambiante, Madrid: Alpuerto, 2016; y las tesis de Vicente Martínez Molés: «Francisco Andreví Castellá y la música española del clasicismo», Tesis Doctoral, Universitat de València, 2015; y María Ordiñana Gil: «Oficio y Misa de Difuntos de Francisco Andreví Castellá (1786-1853) en el contexto de las exequias reales españolas del siglo XIX», Tesis Doctoral, Universidad Católica de Valencia, 2016.

37. Sobre el catálogo de la catedral de Valencia, véase José Climent BARber: La música de la Catedral de Valencia, Valencia: Ayuntamiento de Valencia, 2011.

38. Para un estudio sobre la difusión de la obra de Andreví, véase Ordiñana: Oficio y Misa de Difuntos, pp. 91-141.

39. Josep Rafael Carreras y Bulbena: El oratorio musical, Barcelona: Tip. L’Avenç, 1906, p. 148.

40. «Carta de Andreví al Cabildo del 29 de abril de 1824», Biblioteca Nacional de España, MSS.14059/17/9.
} 
Por desgracia, la catedral no pudo resolver esta situación lamentable del compositor, pero le permitió e incluso se ofreció a pagar los costes para realizar otras oposiciones con el compromiso de avisarle en caso de mejora económica de la institución. Todo ello desembocaría años después en la realización de nuevas oposiciones al magisterio de la catedral de Sevilla, cargo que finalmente ganó el 30 de marzo de 1830 pero que ocupó solamente unos meses. ${ }^{41}$

El 31 de julio de 1830 fue nombrado maestro de música de la Real Capilla de Fernando VII, al mismo tiempo que Rector del Real Colegio de Niños Cantores. La participación directa en la demostración pública de la ciudad de Valencia por el paso de la futura reina de España podría haberle beneficiado en la obtención del principal puesto musical en España. ${ }^{42}$

\section{LOCALIZACIÓN Y VALORACIÓN DE LA OBRA EN EL REPERTORIO CATALOGADO DE FRANCISCO ANDREVÍ}

Como se ha visto, el periodo de Francisco Andreví en la catedral de Valencia fue una de sus etapas de mayor estabilidad y en la que desarrolló una intensa actividad musical. Además del voluminoso repertorio que el compositor legó a la institución, se constata la existencia de otras obras compuestas durante su estancia en la catedral de Valencia, pero cuyas partituras han sido localizadas en otros archivos. Este es el caso, entre otros, de la obra objeto de estudio que fue localizada en el Archivo Histórico Comarcal de Cervera (bajo la signatura Caja 10/7). Es precisamente en este archivo donde se conservan más obras del compositor, si bien es cierto que una gran parte están incompletas o en mal estado de conservación. ${ }^{43}$

Se desconoce pues la procedencia de esta fuente y, a pesar de que la mano de copista no coincide con la de Andreví, no se descarta que sea la partitura utilizada para tal ocasión. Cabe considerar que, al tratarse de una obra profana no destinada al culto de la catedral sino a un acto público, esta formara parte de la biblioteca personal del maestro, la cual parece que fue depositada finalmente en el Archivo Histórico Comarcal de Cervera.

Tampoco se indica propiedad ni está marcada por otros cuños más allá del propio del archivo de Cervera. Con todo, es posible que proviniera del que fue maestro de capilla de la parroquia de Santa María de Cervera en el

41. Ordiñana: Oficio y Misa de Difuntos, pp. 54-58.

42. Ballús y Ezquerro: Música en imágenes: Francisco Andreví, p. 289.

43. La localización y recuperación de esta obra en el Archivo Histórico Comarcal de Cervera pone de manifiesto la importancia en el vaciado y estudio de archivos locales, dado que, en ocasiones, las composiciones no se hallan custodiadas en las instituciones para las que fueron compuestas. 
siglo XIX, Ignasi Esteve, ya que consta como propietario de la mayor parte de la obra contenida en el mismo archivo. A su vez, tal como indica Puig, parece ser que esta partitura -junto con el resto del fondo- llegó al maestro Esteve de la mano de su tío Cristòfol Farré, maestro de capilla de la misma iglesia en tiempos de Andreví. ${ }^{44}$

Respecto a su descripción, en la caja estudiada se conserva la partitura manuscrita completa (66 páginas) con orden, de arriba abajo: violín $1^{\circ}$, violín $2^{\circ}$, viola, flauta, clarinete $1^{\circ}$, clarinete $2^{\circ}, 2$ trompas, clarín, fagot, trombón, tiples y tenores $1^{\text {os }}$, tiples y tenores $2^{\text {os }}$, bajos, acompañamiento [violonchelo] y pianoforte. El título de la portada apunta: 3251 / Cantata / Que a la Reyna N[uestr] a S[eño]ra D[o]ña Maria / Cristina de Borbón, en su tránsito por / la Ciudad de Valencia, dedicó el E[xcelentísi]mo Ayun / tamiento de la misma, el día 29 de Noviembre / del año 1829 / Puesta en Música por el Maestro de Capilla de la/ Metropolitana Iglesia de la misma Ciudad / D[on] Fran[cis]co Xavier Andrevi. ${ }^{45}$

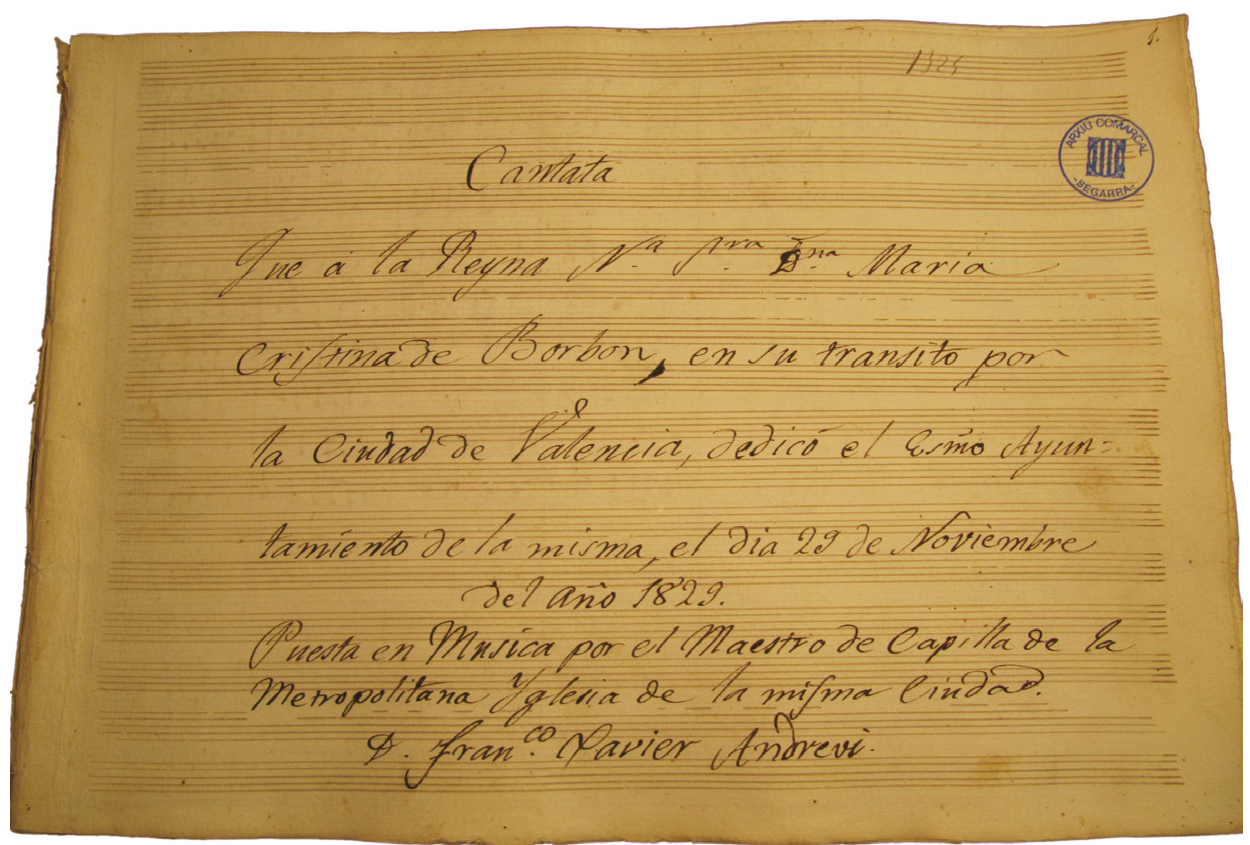

Ilustración 3. Andreví, Portada de la Cantata dedicada a María Cristina de Borbón, 1829, Archivo Comarcal de Cervera (E:CEc), Caja 10/7

44. Xavier Puig: «L'obra de Francisco Andreví i Castellà (Sanaüja 1786-Barcelona1853), músic segarrenc», en Miscel.lània Cerverina, 11, 1997, p. 131.

45. Archivo Histórico Comarcal de Cervera (E:CEc), Caja 10/7. 


\section{ANÁLISIS MUSICAL DE LA CANTATA EN CLAVE DE SUS IMPLICACIONES POLÍTICAS}

Una vez contextualizado el momento y enclave en el que fue interpretada esta obra, cabe analizar sus aspectos musicales con respecto a la función específica para la cual fue concebida la Cantata: la alabanza del pueblo valenciano no solo al próximo enlace real, sino también a la monarquía hispánica y el recto proceder de Fernando VII.

En este punto, cabe considerar que la localización de esta pieza ha sido clave en el estudio de la producción musical de Andreví. Su género de carácter profano, frente al conjunto del repertorio eminentemente religioso que se conoce del maestro Andreví, es altamente significativo para determinar su estilo musical, así como su postura en relación con la corte española.

Así pues, el primer aspecto en el que es posible constatar esa función propagandística estaría en el propio texto de la Cantata, de autor desconocido, el cual se reproduce a continuación en su totalidad: ${ }^{46}$

\section{MARCHA \\ Vuela rauda Cristina, y cual astro Que difunde esplendente fulgor, Tu belleza y virtud resplandezcan Sobre el trono opulento español. Vuela, vuela, llevada en las alas, Que propicio te preste el amor, A colmar los ardientes deseos De Fernando y la Ibera Nación.}

\section{RECITADO}

En viudez dolorosa, en lloro acerbo, Y de anhelada sucesión privado Era el Monarca amado,

Que la parca inflexible por tres veces Esgrimió su guadaña

Contra tres Reinas de la triste España.

La Nación acuciosa

Pide al Rey una Esposa:

Él entonces sus votos atendiendo

Recorre cuanto encierra

Entre cristianos Príncipes la tierra;

Y tu virtud, talento y hermosura

Su corazón enciende

En la llama de amor activa y pura.

46. Memoria de los regocijos públicos con que el excelentísimo ayuntamiento..., p. 14. Consúltese, asimismo: E:CEc, Caja 10/7. 


\section{CORO}

Si la obediencia un tiempo,

O la razón de estado,

O el consejo privado

Fijaron su elección:

A ti ioh bella Cristina!

Solo el amor te llama

Que a nuestro Rey inflama

Y el bien de la Nación.

\section{CAVATINA}

Ve pues al trono,

donde Fernando

con pompa augusta

te está esperando.

$\mathrm{Ve}$ y en su trono,

cual cara Esposa

la pena ahuyente

tu faz gozosa.

Dulce concordia,

grata armonía

reine en Iberia

desde aquel día.

Y el tierno fruto,

de tu himeneo

llene y complete

nuestro deseo.

Para que alegres

y bien hadados,

digamos todos

alborozados:

Felices siglos,

viva Cristina

y el que a la España

nos la destina.

\section{CORO}

Si la obediencia un tiempo etc.

\section{MARCHA}

Cuán la aurora disipa las sombras

Que la noche ominosa esparció;

Desvanece con leda presencia

La tristura, la pena, el dolor:

Y se estrella de paz y esperanza,

De consuelo, alegría y unión, 
Que cual iris benigno aparezca

Sobre el vasto horizonte español.

Sigue, sigue las huellas gloriosas Que el augusto Francisco trazó, Y transmite sus bellas lecciones A una larga y feliz sucesión.

De esta suerte, colmados los votos Que la Hesperia a tu vista formó, Otro trono te ofrece en su centro Cada fiel y leal corazón.

La alusión a las virtudes de la princesa -con palabras como «belleza», «talento» $\mathrm{y}$ «hermosura»- y, muy especialmente, a su futuro como reina de España da prueba de la exaltación del poder real en esta obra, al mismo tiempo que mantiene el discurso oficial en torno a las causas del enlace por la esperada sucesión.

En cuanto a los aspectos musicales, se incluyen una serie de características y rasgos estilísticos que refuerzan el mensaje textual, creando una unión de lenguajes artísticos.

En primer lugar, la forma de la pieza, iniciada y terminada con una marcha, dotan a la obra de un carácter marcial acorde con la letra y el contexto que se representa. La primera indicación de tempo de la composición -Marciale - refuerza el matiz general de la obra, sobre todo dado que caracteriza el movimiento que abre y cierra la composición. El criterio de selección del resto de tempos parece responder a una búsqueda de contraste entre movimientos o secciones con tempos rápidos -Allegro Maestoso y Allegretto- y lentos -Andante y Andante Maestoso-. En la siguiente tabla puede observarse la distribución de los diferentes tempos a lo largo de la Cantata, así como los compases dispuestos entre los que sobresale el compás de compasillo $(\mathrm{C})$. 


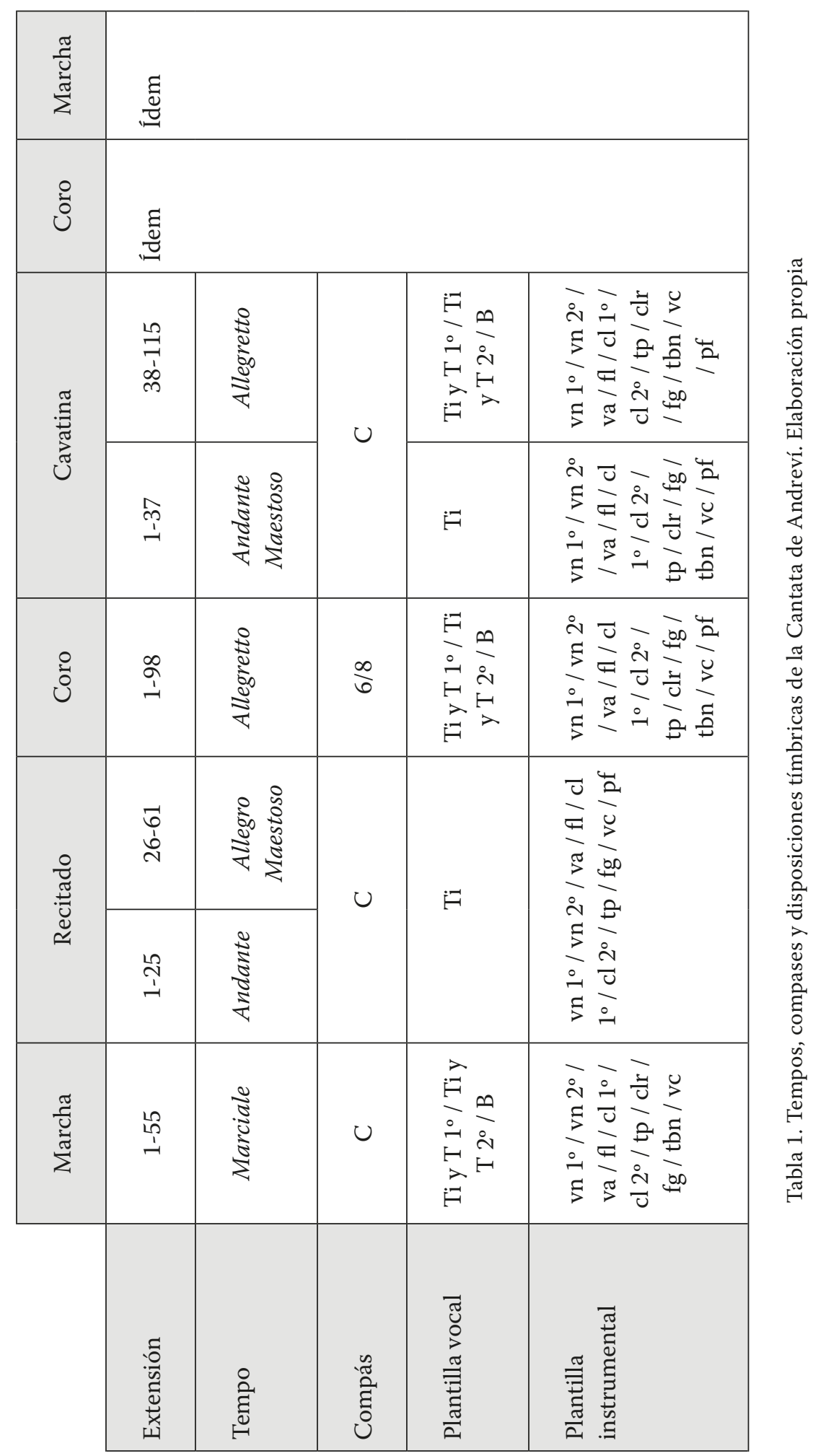


En segundo lugar, cabe hacer mención de la distribución de los instrumentos y voces de esta obra, ya que es determinante para desentrañar su color musical. La Cantata a la Reina María Cristina de Borbón está concebida para un grupo vocal - un coro de tiples (solista, primeros y segundos), tenores (primeros y segundos) y bajos- y un grupo instrumental integrado por una sección de cuerda, viento y pianoforte. La sección de cuerda está formada por violines (primeros y segundos), viola y violonchelo. La sección de viento se distribuye en instrumentos de viento metal -con trompas, clarín y trombón-y viento madera - con flauta, clarinetes (primeros y segundos) y fagot- ${ }^{47}$ Con esta disposición, a pesar de no disponer de una aproximación a la plantilla en cuanto a efectivos, puede considerarse que existe un equilibrio sonoro, aunque con cierta predominancia de la tímbrica de viento metal. Por último, cabe indicar que el grupo instrumental al completo está presente en todos los movimientos de esta obra, a excepción del pianoforte en la marcha y el clarín y el trombón en el recitado. En la tabla anterior, se incluye información al respecto de las variaciones tímbricas entre los movimientos y secciones. El grado de contraste es notorio especialmente por las variaciones tímbricas del recitado y del Andante Maestoso de la cavatina, lo que dota de amenidad a la obra.

Junto con la forma y la tímbrica, en este apartado cabe referirse a las características del material temático destacando los elementos estilísticos -sonido, ritmo, melodía y armonía- que dotan de un carácter propio a la obra y muestran el estilo compositivo de su creador. ${ }^{48}$ Es por ello que, en la siguiente tabla, se han incluido descripciones del material temático de cada movimiento haciendo referencia a uno o varios elementos estilísticos que sobresalen por encima de los demás o que son identificativos de un tema.

47. Como puede observarse, Andreví emplea el fagot en lugar del bajón tal como sucedía desde comienzos del siglo XIX. Véase: María Antonia Virgili: «La Música religiosa en el siglo XiX español», en EMILIO Casares Rodicio y Celsa Alonso González (eds.): La Música Española en el siglo XiX, Universidad de Oviedo, Oviedo, 1995, p. 381.

48. Si bien no es objeto de este artículo sistematizar todos los procedimientos compositivos de esta obra, en este apartado se extraen sus rasgos distintivos analizando el uso que hace Andreví de los parámetros del lenguaje musical. Un estudio pormenorizado de piezas similares, junto con futuros trabajos sobre el estilo compositivo de Andreví, permitirá analizar con mayor sofisticación los procedimientos compositivos y el grado de originalidad de esta composición. 


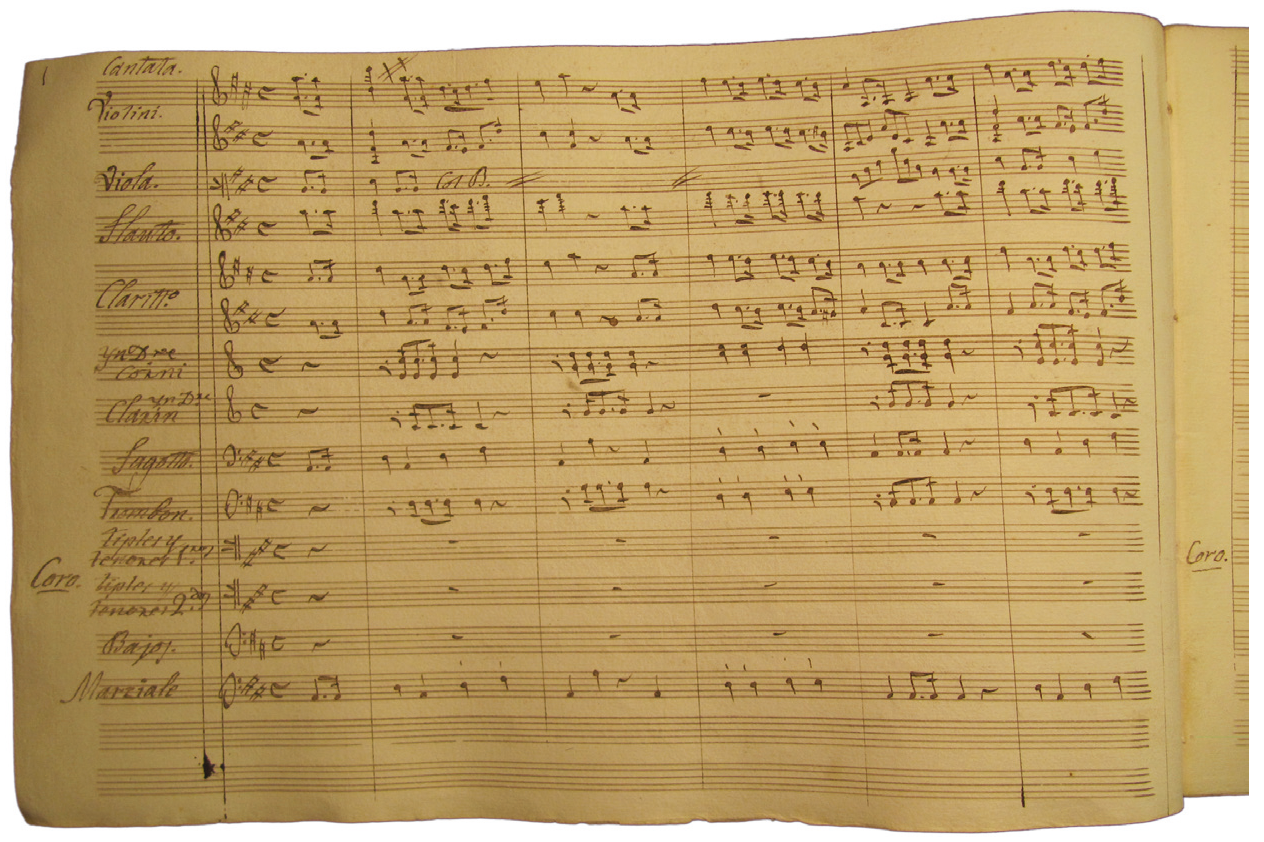

Ilustración 4. Disposición de las voces e instrumentos en la marcha de la Cantata de Andreví, Archivo Comarcal de Cervera (E:CEc), Caja 10/7

\begin{tabular}{|c|c|c|}
\hline Sección & Tempo & Características del material temático \\
\hline Marcha & Marciale & $\begin{array}{l}\text { - Ritmos anacrúsicos y puntillados. } \\
\text { - Acentuación: dinámica marcada ('). } \\
\text { - Saltos melódicos de cuartas y octavas justas. } \\
\text { - Región principal: Re mayor. }\end{array}$ \\
\hline \multirow[b]{2}{*}{ Recitado } & Andante & $\begin{array}{l}\text { - Ritmos anacrúsicos y puntillados. } \\
\text { - Cromatismos. } \\
\text { - Región principal: Re menor. }\end{array}$ \\
\hline & $\begin{array}{l}\text { Allegro } \\
\text { Maestoso }\end{array}$ & $\begin{array}{l}\text { - Estilo melismático. } \\
\text { - Pasajes con ritmo entrecortado. } \\
\text { - Solos del tiple sin instrumentación. } \\
\text { - Región principal: Re mayor. }\end{array}$ \\
\hline
\end{tabular}




\begin{tabular}{|c|c|c|}
\hline Sección & Tempo & Características del material temático \\
\hline Coro & Allegretto & $\begin{array}{l}\text { - Figuraciones excepcionales (seisillos). } \\
\text { - Ritmos anacrúsicos. } \\
\text { - Textura homofónica con pequeñas variaciones } \\
\text { rítmicas. } \\
\text { - Región principal: Sol mayor. }\end{array}$ \\
\hline \multirow[b]{2}{*}{ Cavatina } & $\begin{array}{l}\text { Andante } \\
\text { Maestoso }\end{array}$ & $\begin{array}{l}\text {-Textura melodía acompañada (solo del tiple). } \\
\text { - Estilo melismático (bel canto) con gran virtuosismo. } \\
\text { - Región principal: Re mayor. }\end{array}$ \\
\hline & Allegretto & $\begin{array}{l}\text { - Textura solo-ripieno (tiple-coro). } \\
\text { - Creación de clímax sonoros con progresiones y } \\
\text { melodías muy activas (subdivisiones y figuraciones). } \\
\text { - Regiones principales: La mayor - Re mayor. }\end{array}$ \\
\hline
\end{tabular}

Tabla 2. Características del material temático de la Cantata de Andreví. Elaboración propia

Como puede verse, por un lado, Andreví emplea de forma muy efectiva una serie de recursos estilísticos que evocan un estilo militar. Los toques breves de los metales (trompas, clarín y trombón), el ritmo puntillado (corchea con puntillo y semicorchea) y los saltos de cuarta justa hacen que su carácter se aproxime más a un himno. Cabe destacar, además, la tonalidad principal en Re mayor pues le confiere un aire brillante asociado al poder monárquico.

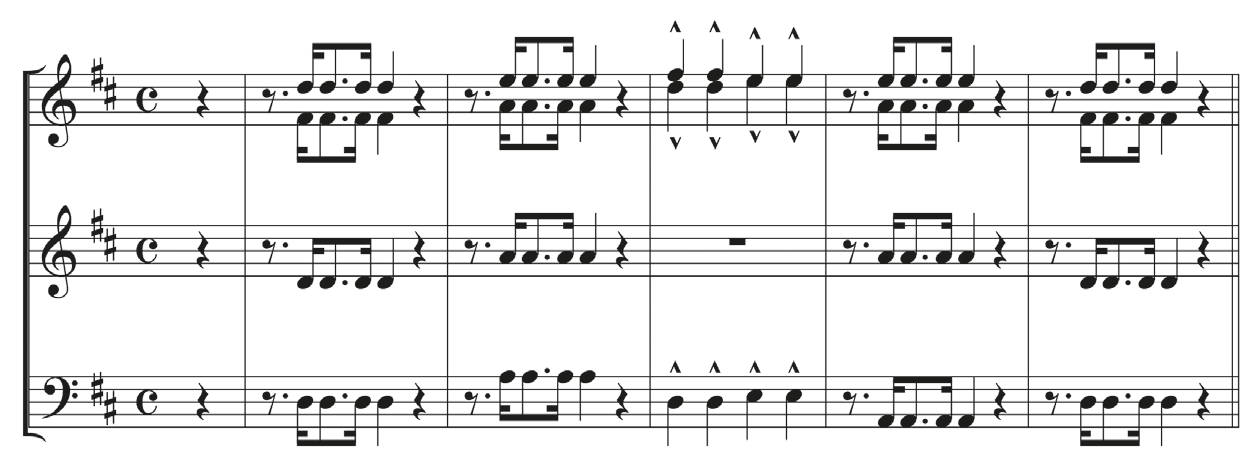

Ejemplo 1. Extracto de la marcha de inicio de la Cantata (cc.1-5; Trompas, clarín y trombón). Elaboración propia 
Por otro lado, también están presentes rasgos estilísticos propios del compositor y del momento histórico, como es la yuxtaposición de elementos compositivos de diferentes épocas o estilos: una simetría en la estructuración de las frases y una tendencia teatralizante con la presencia de cadencias y florituras. Todo ello es empleado por Andreví al servicio de la expresividad que en este contexto se demanda por ser la música representante del soberano y sus designios.

Por último, con el propósito de indagar el grado de coherencia con el discurso de este acto, cabe hacer mención de la relación música-texto en los dos niveles compositivos en los que se produce generalmente: el nivel estructural y el nivel expresivo.

En cuanto al nivel estructural, el texto es clave en la configuración de los movimientos y secciones. Estas últimas están concebidas según la estructura del texto y, en términos generales, siguen los signos de puntuación. Se dan dos estilos principales de musicalización del texto con pasajes de estilo silábico y otros claramente melismáticos influenciados por el bel canto italiano (Véase Ejemplo 2).

Respecto al nivel expresivo, se ha encontrado una serie de palabras o breves frases que son subrayadas por el discurso musical produciéndose una adecuación música-texto, aunque de forma puntual. Es el caso del vítor «viva Cristina» del Allegretto de la cavatina donde se produce un clímax sonoro, precedido de una progresión ascendente, con trémolos en las cuerdas y la participación de la totalidad del coro. Otro ejemplo, en el mismo movimiento, se sitúa en el verso «nos la destina» también destacado con un clímax sonoro de final de sección y con una duración de 15 compases.

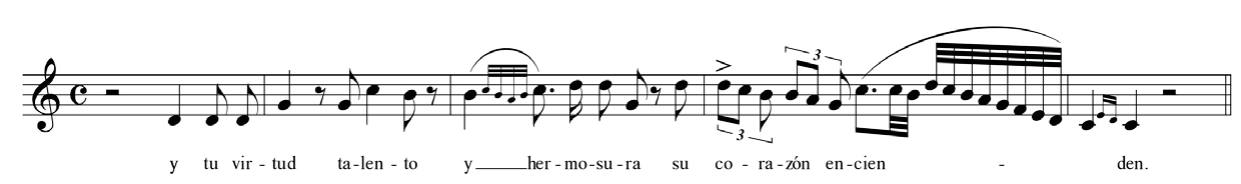

Ejemplo 2. Extracto del recitado de la Cantata (cc. 53-57; tiple). Elaboración propia 


\section{CONCLUSIONES}

En la reconstrucción del viaje de María Cristina al encuentro con Fernando VII se ha constatado la notoriedad que este acontecimiento supuso para el pueblo español y, muy decididamente, la ciudad de Valencia. La desesperación ante la necesidad de consolidación del trono se vislumbra en la magnificencia de estos acontecimientos festivo-ceremoniales, donde la monarquía manifiesta su poder y los súbditos el grado de vasallaje y fidelidad.

El recibimiento llevado a cabo por la ciudad de Valencia fue uno de los más célebres y en él participaron multitud de corporaciones e instituciones. El Ayuntamiento tuvo un papel muy activo como organizador del evento y transmisor e intermediario entre el poder real y la sociedad. La decoración, los bailes, la poesía y la música fueron minuciosamente preparadas como parte de un discurso de apoyo no solo hacia el enlace real, sino también al poder monárquico. La Cantata a la Reina María Cristina de Borbón (1829) de Andreví se presenta como una muestra más de fidelidad en este contexto y cumple con su función propagandística. Con el análisis de esta obra se pone de manifiesto su temática laudatoria sobre las virtudes de la princesa $-\mathrm{y}$ su futuro como reina de España- $\mathrm{y}$ un estilo musical caracterizado por la preponderancia de los metales, los ritmos puntillados o marciales y el empleo de tonalidades con aire brillante.

Por último, la valoración de esta obra ha corroborado la maestría e importancia del compositor Francisco Andreví durante su estancia en la catedral de Valencia. Su trayectoria y actividad musical en esta ciudad fueron claves para tal encargo y responsabilidad. Andreví yuxtapone en esta obra sus propios rasgos estilísticos con elementos compositivos acordes al texto y el carácter que el contexto demanda. Tal muestra de destreza fue, muy probablemente, un estímulo para su posterior destino en Palacio como maestro de la Real Capilla de Madrid.

\section{BIBLIOGRAFÍA}

Alba PagÁn, Ester: «El arte efímero y los artistas valencianos en la primera mitad del siglo XIX: de la fiesta barroca a la fiesta político-patriótica (1802-1833) (I)», Cuadernos de Arte e Iconografía, 16, 1999, pp. 493-530.

-: «El arte efímero y los artistas valencianos en la primera mitad del siglo XIX: de la fiesta barroca a la fiesta político-patriótica (1802-1833) (II)», Cuadernos de Arte e Iconografía, 19, 2001, pp. 183-212.

—: «La pintura y los pintores valencianos durante la guerra de la independencia y el reinado de Fernando VII», Tesis Doctoral, Universitat de València, 2003.

-: «Vicio y virtud en la alegoría de exaltación monárquica: del fin del Antiguo Régimen al liberalismo», en Rafael Zafra Molina y José Javier Azanza López (coor.): Emblemática 
trascendente: hermenéutica de la imagen, iconología del texto, Universidad de Navarra, Navarra, 2011, pp. 137-148.

Álvarez Martínez, María SAlud: «Una serenata de Felipe Falconi para la boda de la infanta María Ana Victoria», en Revista de Musicología, 20, 1997, pp. 343-354.

Ballús Casólica, Glòria y Ezquerro Esteban, Antonio: Música en imágenes: Francisco Andreví (1786-1853), músico de iglesia y compositor cosmopolita en un mundo cambiante, Madrid: Alpuerto, 2016.

Bombi, ANDREA: «La música en las festividades del palacio Real de Valencia en el siglo XVIII», Revista de Musicología, 18, 1995, pp. 175-228.

Bordas Ibáñez, Cristina, Robledo Estaire, luis, Knighton, Tess y Carreras Ares, JuAN José (coor.): Aspectos de la cultura musical en la corte de Felipe II, Madrid: Fundación Caja Madrid-Alpuerto, 2000.

Carreras y Bulbena, Josep Rafael: El oratorio musical, Barcelona: Tip. L'Avenç, 1906.

Climent Barber, José: La música de la Catedral de Valencia, Valencia: Ayuntamiento de Valencia, 2011.

Decretos del rey Nuestro Señor Don Fernando VII, y Reales Órdenes, Resoluciones y Reglamentos Generales expedidos por las Secretarias de Despacho Universal y Consejos de S.M. desde I ${ }^{o}$ de Enero hasta fin de Diciembre de 1829. Josef MARía DE Nieva, tomo decimocuarto, de orden de S.M., Madrid: Imprenta Real, 1830.

Descripcion del viage de sus magestades D. Francisco I y Da. Maria Isabel, Reyes de Nápoles, de la Princesa Real Da. Maria Cristina, futura Reina de España, de S.A. la Duquesa de Berri y de los Serenísimos Señores Infantes de España D. Francisco de Paula y Da. Luisa de Borbón, Valencia: José Gimeno,1829.

De la Torre Molina, María José: «Música y ceremonial en las fiestas reales de Proclamación de España e Hispanoamérica (1746-1814)», Tesis Doctoral, Universidad de Granada, 2003.

— : «Música y ceremonial en las fiestas reales de Proclamación de España e Hispanoamérica (1746-1814)», Granada: Editorial Universidad de Granada, 2004.

-: «La música en las Fiestas Reales de la Málaga Napoleónica (1810-1812)», en Revista de Musicología, 32, 2009, pp. 447-473.

FerRer Martí, SuSANA: «Arte efímero decimonónico: las fiestas reales y político-patrióticas en la ciudad de Valencia», Tesis de licenciatura, Universitat de València, 1993.

Gil SAlinas, RAFAel: «El símbolo de lo Real: La construcción de la imagen de la monarquía española en el tránsito de los siglos XVIII al XIX», en CONCHA LOMBA y JuAN Carlos LozAno (eds.): El recurso a lo simbólico: reflexiones sobre el gusto, II, Actas del simposio, Institución Fernando el Católico, Zaragoza, 2014, pp. 91-117.

Hernández Perelló, Mari Carmen y Reig Baldó, Sara: «La permanencia de lo efímero. Primeras plasmaciones: Los monumentos erigidos en las visitas de la reina María Cristina a la ciudad de Valencia (1829-1844)», en Archivo de arte valenciano, 88, 2007, pp. 75-82.

Knighton, Tess y Morte García, Carmen: «Ferdinand of Aragon's entry into Valladolid in 1513: The triumph of a Christian King», Early Music History, 18, 1999, pp. 119-163.

Lolo, Begoña: «La música en la Real Capilla después de la Guerra de la Independencia. Breve esbozo del reinado de Fernando VII», en Cuadernos de Arte, 26, 1995, pp. 157-169.

—: «Las bodas de Carlota Joaquina con Joao VI (1785)», en José Martínez Millán y María Paula Marçal Lourenço (coor.): Las relaciones discretas entre las Monarquías Hispana y Portuguesa: Las Casas de las Reinas (Siglos XV-XIX). Actas del Congreso Internacional, Polifemo, Madrid, 2008, pp. 1847-1884 (Volumen 3).

Martínez Molés, Vicente: «Francisco Andreví Castellá y la música española del clasicismo», Tesis Doctoral, Universitat de València, 2015.

Memoria de los regocijos públicos con que el excelentísimo ayuntamiento de la muy noble, leal y fidelísima ciudad de Valencia celebró el tránsito y permanencia de los muy excelsos y poderosos reyes de las Dos Sicilias, y de su augusta hija la princesa doña María Cristina de Borbón, en su viage a Madrid, con motivo del augusto enlace de S.A. con el rey 
nuestro Señor (que Dios guarde) publicada por dicha Corporación, Valencia: Imprenta de D. Benito Monfort, 1830.

Mínguez Cornelles, Víctor y Rodríguez Moya, Inmaculada: Las ciudades del absolutismo: arte, urbanismo y magnificencia en Europa y América durante los siglos XV-XVIII, Castellón de la Plana: Publicaciones de la Universitat Jaume I, 2006.

Mínguez Cornelles, Víctor: «La iconografía del poder. Fernando VII y José I. Apoteosis y escarnio en la disputa del trono español», en Alberto Ramos Santana y Alberto Romero Ferrer (eds.): 1808-1812: los emblemas de la libertad, Universidad de Cádiz, Cádiz, 2009, pp. 163-194.

Monteagudo Robledo, María Pilar: «El poder monárquico. Fiestas reales e imagen de la monarquía en la Valencia del Siglo XVIII», Tesis Doctoral, Universitat de València, 1994.

—: «Fiestas reales en la Valencia moderna: El espectáculo del poder de una monarquía ideal», en Estudis: revista de historia moderna, 20, 1994, pp. 323-327.

Morales, Nicolás: «Real Capilla y Festería en el siglo XVIII: nuevas aportaciones para la historia de la institución musical palatina», en Revista de Musicología, 22, 1999, pp. 175-208.

Navarro Lalanda, Sara: «Un modelo de política musical en una sociedad liberal: María Cristina de Borbón-Dos Sicilias (1806-1878)», Tesis Doctoral, Universidad Autónoma de Madrid, 2013.

Ordiñana Gil, María: «Oficio y Misa de Difuntos de Francisco Andreví Castellá (17861853) en el contexto de las exequias reales españolas del siglo XIX», Tesis Doctoral, Universidad Católica de Valencia, 2016.

Pérez Galdós, Benito: Los apostólicos; Un faccioso más y algunos frailes menos, Madrid: Administración de La Guirnalda y Episodios Nacionales, 1885.

Puig, Xavier: «L'obra de Francisco Andreví i Castellà (Sanaüja 1786-Barcelona1853), músic segarrenc», en Miscel-lània Cerverina, 11, 1997.

RifÉ i SANTAló, Jordi: «La música en Girona durante la visita del archiduque Carlos de Austria», en Revista de Musicología, 20, 1997, pp. 331-342.

RODRÍGUEZ MOYA, INMACULADA: «Epitalamios e himeneos. Iconografía y literatura nupcial en las cortes del Barroco», en Imago. Revista de Emblemática y Cultura Visual, 2, 2010, pp. 7-24.

-: Himeneo en la corte: poder, representación y ceremonial nupcial en el arte y la cultura simbólica, Madrid: Editorial CSIC Consejo Superior de Investigaciones Científicas, 2013.

Ros-FÁbregas, Emilio: «Music and ceremony during Charles V's 1519 visit to Barcelona», en Early Music History, 23, 1995, pp. 374-389.

Virgili María, Antonia: «La Música religiosa en el siglo XiX español», en Emilio CaSARes Rodicio y Celsa Alonso González (eds.): La Música Española en el siglo XIX, Universidad de Oviedo, Oviedo, 1995.

\section{HEMEROGRAFÍA}

Diario de Barcelona, 319-323, 1829.

Diario de Valencia, 59, 1829.

Diario de Valencia, 60, 1829.

Diario de Valencia, 62, 1829.

Diario de Valencia, 63, 1829.

Mercurio de España, 10, 1829.

Mercurio de España, 11, 1829.

Mercurio de España, 12, 1829. 


\section{FUENTES INÉDITAS}

«Actas y documentos pertenecientes a la comisión de festejos a la venida de SSMM, año 1829», AMV, FIESTAS, FERIAS Y ESPECTÁCULOS, CLASE I, SUBCLASE B: Fiestas Reales.

«Antecedentes de festejos por la venida de los Reyes de las dos Sicilias y la Serenísima Señora Infanta Doña Cristina futura Reina de España», Archivo Municipal de Valencia (AMV), FIESTAS, FERIAS Y ESPECTÁCULOS, CLASE I, SUBCLASE B: Fiestas Reales.

«Cantata / Que a la Reyna N[uestr]a S[eño]ra D[o]ña Maria / Cristina de Borbón, en su tránsito por / la Ciudad de Valencia, dedicó el E[xcelentísi]mo Ayun / tamiento de la misma, el día 29 de Noviembre / del año 1829 / Puesta en Música por el Maestro de Capilla de la/ Metropolitana Iglesia de la misma Ciudad / D[on] Fran[cis]co Xavier Andreví», Archivo Histórico Comarcal de Cervera (E: CEc), Caja 10/7.

«Carta de Andreví al Cabildo del 29 de abril de 1824», Biblioteca Nacional de España, MSS.14059/17/9.

Francisco Ferrer: «Plano geométrico de la ciudad de Valencia llamada del Cid», Biblioteca Valenciana, 1831, CartografíaAnt7/6. 